\title{
Single-Minded Homolog 1
}

National Cancer Institute

\section{Source}

National Cancer Institute. Single-Minded Homolog 1. NCI Thesaurus. Code C75510.

Single-minded homolog 1 (766 aa, $\sim 86 \mathrm{kDa}$ ) is encoded by the human SIM1 gene. This protein is involved in transcriptional regulation and embryonic development. 